\title{
The counter-revolution of criminological science: a study on the abuse of reasoned punishment
}

\author{
DANIEL D'AMICO
}

Brown University

\begin{abstract}
Trends in the history of social science dedicated to the study of crime and punishment are presented as a case study supporting F.A. Hayek's theory of social change. Designing effective social institutions and public policies first requires an accurate vision of how society operates. An accurate model of society further requires scientific methods uniquely suited for the study of human beings as purposeful agents and the study of human institutions as complex social phenomena. If guided by faulty methods, theories are inaccurate and policy outcomes veer from their intentions. Hayek termed such outcomes "abuses of reason". Aiming to replicate the objectivity of physical sciences via formal modeling and statistical measurement, economists throughout the 20th century imposed an excessively technical vision of human decision-making. Policy failures and social problems resulted. This paper argues that the historical trends of applied social science dedicated to crime and punishment can be understood similarly. Formal modeling and statistical measurement continuously displaced methods more attuned to human intentionality and social complexity. In result, amidst a long-run history of intellectual and political change, US law enforcement and criminal punishment policies became technocratic, and outcomes became disjointed from their stated intentions to promote social order and welfare.
\end{abstract}

Keywords: criminology, punishment, scientism, methodology, Hayek

JEL Classification: B15, K42

AUTHOR'S NoTE: The author would like to thank Adam Martin and Nicholas Snow for helpful feedback on earlier drafts, as well as the participants of the Workshop in Philosophy, Politics and Economics at George Mason University. Two anonymous referees provided helpful commentaries that much improved the final manuscript. 
Discipline in general, like its most rational offspring, bureaucracy, is impersonal. Unfailingly neutral, it places itself at the disposal of every power that claims its service and knows how to promote it.

-Weber $(1946,254)$

\section{INTRODUCTION}

In recent years, US criminal justice policies and outcomes have arisen deep concern. Extreme growth, fiscal unsustainability, and racial disparity are widely recognized features of the US prison industrial complex. Overcriminalization, heightened sentencing, police militarization, and the excessive use of force are all additional areas of concern. While it is well understood that these contemporary trends have deep seated political, cultural, economic and historical roots, such trends cannot be fully explained with references to real crime rates or other features of US exceptionalism. The need for reform is popular amongst experts and citizens alike. But, the question remains: Why are such outcomes so entrenched and difficult to reshape? What particular reforms will move towards more socially desirable results? And how can such transitions be effectively implemented?

I argue that this tension between the perceived needs for reform on the one hand, with the inability to substantially reshape outcomes on the other, can be at least partially attributed to methodological patterns in the social sciences dedicated to understanding crime and punishment. There is a lack of conclusive explanations for the causes and consequences of crime, as well as an incomplete understanding regarding the potentials, and limitations of different law enforcement and punishment strategies. This theoretical lacuna is not merely for lack of good science, but rather stems from certain shortcomings in the professional, academic, and political environments within which social science is conducted. Methodological orthodoxies therein elevate and insist upon quantitative analyses at the expense of qualitative, descriptive, and comparative alternatives. When in fact, such latter techniques are needed to recognize and cope with those features of our current malaise that specifically stem from the unintended consequences of policy failures. Hence, amidst such methodological trends, error becomes a self-fulfilling prophecy and the potentials for effective reforms narrow.

This analysis draws heavily from F.A. Hayek's (1952) comments surrounding the similar methodological fashions of the economics 
profession amidst the latter part of the 20th century and fits compatibly with Feeley and Simon's (1992) thesis that actuarial standards reshaped the aspirations of prison managers away from rehabilitation and towards more narrow goals of internal behavioral compliance. When scientism insists upon formal modeling and quantification, political incentives promote strategies and policies that conveniently attend to such standards, thus displacing and, at times, suppressing alternative methods that better appreciate and accommodate processes of institutional innovation and experimentation.

In short, criminal justice failures persist, and reform efforts continually fall short, because the conceptual frameworks that are used to understand crime, punishment, and their surrounding public policies and social outcomes are not fully attuned to the factors that shape such problems. Nor are they well geared to recognize the potentials of certain social processes that may be needed for the discovery and implementation of effective reforms. To some degree, criminal justice failures require genuinely innovative thinking and actions to discover and implement preferable outcomes. Not only do political structures suppress incentives for social entrepreneurship, but the professional, academic, and political establishments also reinforce status quo frameworks and techniques against alternative conceptual approaches. As evidence of this claim, I survey methodological trends across a long swath of criminological history. The criminological sciences endured similar methodological trajectories as Hayek (1952) described amongst the economics profession of the 20th century.

It is difficult if not impossible to fully link the detailed global trends of criminal justice policies and outcomes onto any individual theory of social change. Full and accurate data sets regarding the internal operations of criminal justice systems and outcomes, be they quantitative or qualitative, are simply not available for a large sampling of under-developed nations around the world. Stylized empirics of criminological phenomena are perhaps inherently more difficult to obtain relative to those related to other social processes. I choose to focus on how long-run methodological trends of social science can be seen to relate to similarly long-run criminal justice policies and outcomes in the American experience. Hence, the analysis herein should not be seen as fully explanatory of the US experience, nor is it necessarily applicable beyond the US context. My claim is merely that the long-run trajectory of US policy history preceding the morass of 
contemporary criminal justice failures and the persistent incapacity of effective reforms were at least partially shaped by and related to methodological trends within the social sciences during that same longrun history.

Early in America's founding, criminological perspectives drew heavily from the classical school of social science wherein methodological standards focused upon the behavioral conditions of rational decision-making, the coordinative potentials and limitations of inter-individual and group behaviors, and comparative institutional analysis. Hence effective law enforcement and punitive strategies were thought to be a function of matching the unique social conditions and resource constraints of a community with legal procedures reflective of local norms and values. Such was ultimately a challenge of social epistemology. By what institutional processes and mechanisms could communities discover and convey their preferences and knowledge sets regarding criminal justice conditions and resource allocations? The early strength of Federalist checks and balances thus promoted criminal justice institutions that conveniently preserved a large degree of local autonomy. Hence, the early dispersed townships of the American colonies and frontier spaces existed within relatively competitive institutional contexts. The technological and authoritative gap between local law enforcement authorities and individual citizens was small, and the potentials for citizen to exit local jurisdictions in favor of alternative communities were relatively high. Such conditions certainly had their limitations and imperfections but they tended to conveniently avoid many of the types of failures endemic to modern systems. ${ }^{1}$

Later in US history, methodological trends in social science took a more empiricist turn and thus complemented political demands for interventionism. Criminal justice transformed from a largely dispersed and informal institutional network of different local townships and independent administrative units into a more formally hierarchical system unified by overt intentions of social control and improvement. Law enforcement and correctional institutions were newly financed, operated, and aimed towards deterrence, incapacitation, and rehabilitation. Such in turn, provided new opportunities and demands

\footnotetext{
${ }^{1}$ An obvious caveat should be made at this point regarding slavery. Though a full analysis regarding the inter-relationship of criminal law across recognized citizens and subjugated populations is needed, it is far beyond the scope or aims of this paper. For present purposes this paper reserves its focus to the scope of criminal law presiding over only classes of recognized citizens.
} 
for a more quantitative approach to the social science of crime and punishment.

As quantitative data became more reliable and available, theories and techniques followed in stride. Formalistic approaches further complemented political demands for a more professionalized law enforcement system. Larger and more empowered governmental bureaucracies and an increased role of federal-relative to state, or local authority-supposedly provided unique vantages and opportunities for implementing more formalized and quantitative approaches of social science. Law enforcement agencies and officers became less directly assessed by local citizens with regard to their promotion of social order or their effective promotion of community norms. Instead, technical approaches narrowed in upon tangible and measurable performance proxies like reported crime rates, operating expenses, and recidivism rates. Decision-making within criminal justice systems became more bureaucratized and governed by political processes. Overt commitments to the tracking and targeting of such variables thus displaced potentials for alternative institutional innovations through social experimentation in so far as new proposals carried uncertainty regarding their relationships to standard proxies. Thus, professional academic and political outlets for applied social science placed low value on qualitative and comparative methods. Such methodological and practical legacies have narrowed the realm of considered strategies for crime control to typically expansionist and centrally managed proposals. Increased budgets, more technologically sophisticated police weaponry and equipment, tougher laws, bigger prisons, and longer sentences are all obviously incentivized under an ever growing bureaucratized system, but they are all also direct implications of the most dominantly entrenched mental models of social science dedicated to crime and punishment.

The remainder of this paper is organized as follows. Section II explains Hayek's theory of social change foundationally driven by methodological trends in the social sciences. I argue that similar trends can be seen throughout the dedicated social science treatments of crime and punishment. Sections III to VI survey various schools of applied social science on crime and punishment popular and influential during US history: section III surveys the classical school, section IV the positivist school, section V the Chicago school, and section VI the most recent approaches to researching crime and punishment. Each 
framework's methodological and topical traits can be seen as counterrevolutions from previous perspectives. Stemming from methodological dilemmas, criminal justice institutions historically grew unreasoned from their stated social functions. Section VII concludes.

\section{HAYEK'S THEORY OF SCIENTISM}

Beneath the research heading, "on the abuse \& decline of reason", ${ }^{2}$ Nobel economist Hayek wrote, "it is human ideas which govern the development of human affairs" $(1952,3) .{ }^{3}$ But, for Hayek, social change was more complex than the cliché adage 'ideas matter'. Rather than positing social trends as the direct result of populist ideologies, Hayek emphasized the role that scientific methodology plays in shaping social outcomes. If ideas drive society, then the procedural origins of ideas matter foundationally. How scientists formulate theories will shape their accuracy and in result, shape real-world consequences. Bad methods lead to bad theories, bad theories lead to bad policies, and bad policies lead to bad outcomes.

Concerned about the challenges of subjective bias, 20th century social scientists-especially economists-adopted formal modeling, hypothesis testing according to statistical measurement, and predictive forecasting. Hayek argued that this trend lost sight of the purposeful nature of human decision-making and thus truncated the treatment of volitional human actions and the formations of complex social institutions into a series of programmable mechanic operations. Machined visions of economic exchange overly simplify the otherwise subtle and complex processes of real human decision-making and social cooperation. Hence, legislating public policies informed by such models carried unintended consequences for social welfare.

Hayek thought many of the social problems of the 20th century stemmed foundationally from a methodological bias within the economics profession. Social scientists writ large suffered the ill of 'scientism'-a general obsession with imposing the techniques of the physical and natural sciences onto the subject matters of human actions

\footnotetext{
${ }^{2}$ The counter-revolution of science was originally published in Economica in 1941 and subsequently with additional material in a book-length treatment under the fuller title, The counter-revolution of science: studies on the abuse of reason (1952). Individualism true and false was a lecture delivered in 1945 and published shortly thereafter within the text Individualism and economic order (Hayek 1948). These materials have been combined, as originally intended, in Hayek (2010).

${ }^{3}$ Hayek (1949) also attempts to explain sociological issues of professional intellectuals and their influence upon ideological and social change.
} 
and social operations. Lightning does not result from the anger of the gods. But, when social scientists purged normativity by embracing formalism, they also inadvertently discarded some necessary techniques for comprehending the distinctive features of their subject matter. Deduction and natural language are perhaps crucial techniques for appreciating and conveying the unique purposefulness of human choices and the socially coordinative operations of institutions. In contrast, formal mathematical models must simplify broad swaths of diversely motivated choices into definable and measurable units. ${ }^{4}$ However, economic policy cannot be understood anathema to the preferences and choices of the human beings living amidst their operation without consequence. Designing economic policy to blindly chase statistical proxies can result in production schemes that are, in fact, out of sync with social welfare. As development economists often quip, 'you can't feed a family with GDP growth rates'.

There is a meaningful difference between the challenges of scientism and merely bad science. Bad science can be recognized as underspecified models, imprecise or inaccurate data, and/or flawed experimental designs. The conclusions of bad science cannot be trusted, but bad science can be corrected and improved upon. Furthermore, the scientific process is, in fact, aimed at the rooting out and correcting of bad science, but it is perhaps less well-alert to the needs of rooting out scientism. Better data and better models allow for better science. Only when such empirical methods appropriately capture and convey the essential features of the subject matters that they aim to explain, does good science inform good public policies.

In contrast, addressing the challenges associated with scientism is more complex, as scientism is a sort of cultural trend within the professional academic and political arenas. Scientism occurs when the formalistic and quantitative methods of the physical sciences are demanded and insisted upon within the social sciences irrespective of their inabilities to fully explain or predict human and social phenomena. No individually designed or constructed model, no matter how precisely

\footnotetext{
${ }^{4}$ This is not to say formalism has not contributed to social science; merely that trends in data, technology, political and professional interests all influence the popularity and dominance of methods among researchers through history. In so far as policies were shaped by misapplied theory, social problems result and persist. Nor is it the case that comparative and procedural analyses are impossible amidst professional formalism. Boettke, Coyne, and Leeson (2003) point out the rise of analytic narrative (Bates et al. 1998) and new institutional economics (North 1990) as hopeful trends returning natural language methods and universal topics to the economics profession.
} 
defined or informed by granulated empirics, is capable of fully reflecting the uniquely complicated and subjectively varying elements of human psychology and purposive behavior. Proxy variables are just that, proxies. They are not direct windows into the community's collective conscience or consciousness. Hence, formal modeling of society within an atmosphere of scientism creates orthodoxies hostile to processes of institutional experimentation and structural change. In so far as genuine social entrepreneurship is needed to discover and implement preferable institutional arrangements and policies, social problems foment and persist amidst scientism.

The problems of scientism most often occur at the intersection of science and public policy. If we accept the basic premise that individuals behave rationally in at least a bounded sense (Kahneman 2003), then it is also reasonable to extend this assumption onto policy makers and political authorities. Hence, political authorities are likely to prefer those methods and conclusions that most insulate and promote their own interests, unless otherwise constrained through constitutional checks and balances (Brennan and Buchanan 2000). Hayek argued such was the relationship between economic science and public policy, as formalism and quantitative analysis promoted political desires to expand centralized control over the economy (Hayek 1935).

Akin to Hayek's model, Boettke, Coyne, and Leeson $(2003,2)$ offer a visual outline to map trends in economic thinking. Methods ranged from formal modeling to natural language; topics from particular case studies to universal theories. Figure 1 graphs these dimensions and places schools of thought within their respective quadrants.

"[T]he movement in economic thinking is composed of four competing visions" (Boettke, Coyne, and Leeson 2003, 1). The first (bottom right quadrant) "verbal economic analysis [...] maintains the universal nature of economic propositions" (2). Economic decisionmaking is seen as a consistent sub-set of a broader and universal vision of human action and such theorizing is conducted in natural language methods of deduction and comparative analytics rather than formal modeling and statistical measurement. 


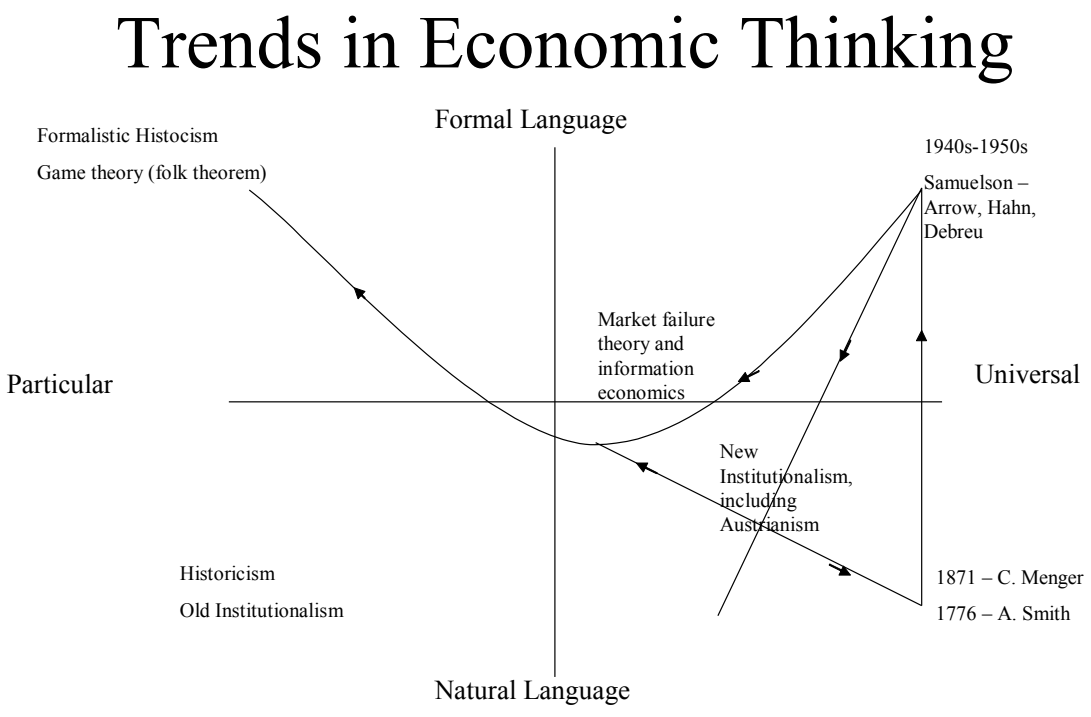

Figure 1.

The second vision (bottom left) shares natural language methods, but "it is believed that economic truths revealed through study are merely particular" (2). There is little to no effort to fit economic analysis within a consistent or universal vision of human decision-making or social operations. Each social context may or may not exhibit its own unique set of causal properties and explanatory principles. In the third (upper right), "the mode of exposition is purely a formal one of mathematical modeling and statistical testing" (2), but it retains a universal element wherein all human actions can be modeled in mathematical terms and such propositions can be tested against quantitative data. The fourth (upper left) uses formal modeling to investigate multiple equilibria rather than universals. Unique contexts of behavioral patterns accord to unique arrangements of mathematical formula, but typically no unifying principles necessarily align these diverse observations and applications.

Boettke, Coyne, and Leeson (2003), like Hayek, see the greatest potential for theoretical accuracy in the social sciences from the first vision. Social processes must be understood within a broader, consistent, and accurate theory of society. In turn, this social theory must rest upon an accurate understanding of human decision-making. A sound theory of human behavior requires a methodology appreciative of the uniquely human features of human decision-making: purposeful 
choice, subjective evaluation, and strategic interaction. Unfortunately, such facets are difficult to capture or convey with statistical aggregates. For example, public policy can too narrowly focus on minimizing unemployment at the expense of other individual or societal aspirations. A bridge built primarily for the sake of job creation risks being a bridge to nowhere (Hazlitt 1946, 32). Similarly, if law enforcement resources are arranged to merely chase arrest rates, clear cases, promote the special interests of police unions, or create jobs in a local economy, they too can work against the more complex needs for peace, security, and social order. Natural language methods are argued to be better equipped at capturing the procedural and adaptive operations of individual and social processes, as formal techniques-especially those deployed amidst the 20th century-imposed a relatively static vision of equilibrium conditions.

In this view, correcting the failed outcomes of policy trends foundationally depends upon correcting the methodological trajectory of the social sciences. We cannot resolve social problems, if we do not first correctly understand their causes. Furthermore, we cannot correctly understand how society operates if we do not have the right scientific methods and analytical tools to investigate the unique and distinctive features of human actions and human society. Hence, correcting the trajectory of methodology within the social sciences depends in part upon relaxing professional and political orthodoxies surrounding scientism. New techniques must be allowed to enter the debate and attempt to arrange the accumulated research and findings into coherent theories that challenge and contest the policy inferences drawn from more mechanical approaches.

I argue that a swath of social problems surrounding the US criminal justice system can be seen as a partial by-product of a process of abused reason akin to Hayek's descriptions of scientism within economics. In so far as the intersections of social science and public policy writ large suffered from the challenges of scientism, so too did focused applications of social science on the topics of crime and punishment. ${ }^{5}$

\footnotetext{
${ }^{5}$ These patterns have been noticed in other applied topics as well. For one example, Boettke and Aligica (2009) explain that Ostrom's (Blomquist 1992; Ostrom and Cole 2011) research in urban planning paralleled the theoretical structure of the socialist calculation debate. Scholars equated centralization with efficiency by presumption. Taubes $(2007 ; 2010)$ argues similar issues plague discussions surrounding public health and nutrition. Easterly $(2002 ; 2007)$ suggests that foreign aid programs endure systemic failure from models lacking variety and complexity in development
} 
Until the early 19th century, the 'classical school' of criminology was largely comprised of political economists who sought to understand crime and punishment within a broader and consistent model of society (akin to the first vision in the bottom right quadrant of figure 1). By the early 1800s, criminology was shifting away from natural language methods towards empirical formalism. Akin to the economic historicists (the second vision within the bottom left quadrant of figure 1), positivist criminology developed theories of biological and social determination. In reaction to ineffectual rehabilitation efforts (Martinson 1974; Lipton, Martinson, and Wilks 1975), the 1960's Chicago school re-introduced rational models of criminal behavior and also eventually embraced mathematical formalism and quantitative analysis (akin to the third vision in the upper right quadrant of figure 1). In the late 20th and early 21st century, the applied studies of crime and punishment have taken form as quantitative case studies of particular times and places (akin to the fourth vision in the upper left quadrant of figure 1).

\section{THE CLASSICAL SCHOOL}

The classical school of political economy possessed unique methodological features relative to later theoretical traditions. Methodological individualism, rational choice, and comparative institutional analysis provided a unique vantage from which classical authors could recognize processes of social order as stemming from spontaneous, decentralized, and unregulated processes. Furthermore, the classical model was keenly equipped to identify the scope of social problems that stemmed from the unintended consequences of failed constructivist policy efforts. This section demonstrates the methodological similarities between the classical school of political economy and the classical school of criminology. Such is a relatively straightforward task as much of classical criminology is in effect a retroactive composition of commentaries provided by classical political economists that happened to touch upon the subjects of crime and punishment.

Hayek $(1948 ; 1973)$ distinguished two threads of individualism within the classical school of political economy. ${ }^{6}$ "True individualists"

economics. Coyne $(2008 ; 2013)$ tracks failures of imposed plans in post-war reconstruction and international policy.

${ }^{6}$ The classical school emerged amidst the Scottish enlightenment more generally, dating to the latter 17 th and 18 th centuries. 
viewed society as an evolutionary process, "the result of human action but not the result of human design" (Ferguson 1996, 187). Hayek (1948, 4) lists Locke, Mandeville, Hume, Tucker, Ferguson, Smith, De Tocqueville, and Acton-who all sought to understand how interacting individual choices spontaneously contribute to social order. What are the universal laws of human action, how do they operate, and by what methods can they be identified and understood (Barry 1982)?

In contrast, Hayek $(1948,4)$ termed constructivist rationality, a form of "false individualism". Descartes and Rousseau spawned the trend and their influence upon Mill and Spencer caused later confusions. To constructivists, individual behavior is universally rational-mechanically so. Such mechanization is arguably the avenue through which methodological formalism eventually took hold amongst the constructivists. Conscious human intention is the predominant drive behind social order, but in this view, mankind has a responsibility to actively promote and impose rational social conditions through institutional designs and control. Hence, formal modeling and measurement become presumed techniques for improving the accuracy and effectiveness of public policy. Bentham's (1907) utilitarianism expressed in formal policies of panopticism is an obvious example. Better technologies of observation and isolation presumably lead to better rates of behavioral compliance. ${ }^{7}$

Perhaps no subject captures the tension between these competing individualisms as well as their respective members' comments surrounding crime, punishment, and incarceration. Comparative historical research using natural language methods led 'true' individualists to recognize structural relationships between enforcement regimes on the one hand, and crime and punishment outcomes on the other. These individualists supported the adaptive and evolutionary features of the common law, favored decentralized authority through constitutional checks and balances, and opposed torture and corporal punishments. ${ }^{8}$ In contrast, constructivists sought to impose quantitative

\footnotetext{
${ }^{7}$ Hayek $(1973,22$, fn. $28 ; 1948,4)$ explicitly mentions Tocqueville as preferable to Bentham.

${ }^{8}$ D'Amico $(2010,465)$ surveys, “John Stuart Mill, though concerned about protection against force and fraud, did not conclude an absolute role of government authority, 'people might be required to protect themselves by their skill and courage even against force, or to beg or buy protection against it, as they actually do where the government is not capable of protecting them' (Mill 1982, 800). Perhaps Mill's assessment of prisons resulted from his own observations. 'Nothing is done to make the prisoner
} 
and predictable influence upon crime and punishment for the supposed betterment of society. Bentham's panopticon designs popularized incarceration as the now standard form of criminal punishment worldwide. Constructivist proposals were more compatible with and appealing to political desires and thus dominated policy and research trends thereafter.

Smith, Beccaria, and several other individualist economists ${ }^{9}$ are also recognized as founding members of the classical school of criminology (Cullen, Agnew, and Wilcox 2002), which situated the study of crime and punishment within a broader effort, "to understand the forces which determine the social life of man, and only in the second instance a set of political maxims derived from this view of society" (Hayek 1948, 6). In other words, support for laissez-faire economic management was not motivated by normative claims to natural rights per se. It was instead a positive inference stemming from the recognized consequences of interventionism. A similar humility regarding the potentials of public policy and a similar focus upon procedural checks and balances characterized true individualist commentaries on crime and punishment.

Individualists viewed the functional aspects of society as the biproduct of unconscious trial, error, and effective endurance. "Man has achieved what he has in spite of the fact that he is only partly guided by reason, and that his individual reason is very limited and imperfect" (Hayek 1948, 8). Those institutions reacting to crime via formally designed law enforcement regimes and punishments are obviously shaped by direct rationality and conscious effort. Thus, any individual program is likely shortsighted, narrowly focused, and prone to errors and imperfections. However, classical thinkers saw the degree to which one law enforcement regime succeeded relative to alternative strategies, more as a consistent bi-product of spontaneous social operations. Preferable criminal laws and enforcement techniques were discovered, implemented, and selected over alternatives through time and across different regimes as part of a long historical process entailing social experimentations and institutional evolutions.

better; and when there is nothing doing to make him better, it is pretty certain, that there is enough doing to make him worse'” (Mill 1982, 105).

${ }^{9}$ Francesco Carrara and Enrico Pessina are lesser-known affiliates. Montesquieu (1989) and Chadwick (1829) are also included. 
Beccaria (1995) writing in Of crimes and punishments explains the limited influence of constructivist rationality in criminal legislation and jurisprudence:

Our knowledge is in proportion to the number of our ideas. The more complex these are, the greater is the variety of positions in which they may be considered. Every man hath his own particular point of view, and, at different times, sees the same objects in very different lights. The spirit of the laws will then be the result of the good or bad logic of the judge; and this will depend on his good or bad digestion, on the violence of his passions, on the rank or condition of the accused, or on his connections with the judge [...].

[E]ach individual, who will always endeavour to take away from the mass, not only his own portion, but to encroach on that of others. Some motives therefore, that strike the senses were necessary to prevent the despotism of each individual from plunging society into its former chaos. Such motives are the punishments established, against the infractors of the laws (8-9).

Smith (2009) similarly saw the functional aspects of criminal law and enforcement as evolved from imperfectly motivated inter-individual behaviors.

The revenge of the injured which prompts him to retaliate the injury on the offender is the real source of the punishment of crimes. That which [...] other writers commonly allege as the original measure of punishments, viz. the consideration of the public good, will not sufficiently account for the constitution of punishments (104).

In this classical view, crime and punishment, like all human behaviors, are seen as generally purposeful and responsive to incentives. Though individual choices are reasoned, their intentions are determined subjectively. Individuals may be ignorant, or strive for goals not understood by others. But, in so far as punishments are perceived harmful and costly to criminal actors, increasing the severity of punishment and/or the reliability of its application-like raising consumer prices-should, ceteris paribus, deter criminal behaviors. The ceteris paribus presumption carries a hefty weight of the analytical traction.

This purposeful view of crime does not provide a practical blueprint for punishment strategies within any particular social context, let alone across different environments. Exogenous factors are rarely ever held 
constant in the real world. What types and magnitudes of punishment prove efficient in a particular time and place, requires knowing the varied costs and benefits of criminal behaviors therein, compared to their relevant enforcement strategies and opportunity costs.

Individualists possessed a relatively limited sample of social observations and theories to inform their causal models of crime and punishment, but they were nonetheless early to notice a meaningful relationship between varied enforcement regimes with crime and punishment outcomes. For Smith (1982; 2009) pervasive criminal acts such as "raping, pillaging and plundering" $(1904,25)$ impede economic development and social order. He thus identified well-functioning legal systems by their abilities to harmonize human intentions through "trucking, bartering and exchanging" $(1904,25) .{ }^{10}$

Specifically on the topic of penal policies, Alexis de Tocqueville's research took a similar comparative approach to Smith and other classical authors. Bauemont and Tocqueville (1833) were initially sent to America, among many other state officials (Johnston 2000), to investigate prison facilities as a potential source to early American exceptionalism. Hence, the structure of their empirical report took form as a survey of criminal legal policies, enforcement patterns, and internal management styles viewed across prison facilities in various townships throughout the early United States. Such methods were clearly mimicked in Tocqueville's more prominently known Democracy in America (1990a; 1990b)-also drafted from research and observational accounts garnered during his initial nine-month prison voyage.

Tocqueville exemplified the individualist perspective regarding his usage and reliance on core assumptions concerning human rationality and purposeful motivations. Criminal agents were seen as motivated by strategic plans, responsive to incentives, and shaped by the complex processes of social cooperation and coordination. Tocqueville also shared the classical concern against excessive punitive authority wielded by state governments. Prisons were only effective in so far as they were small and infrequently relied upon (Whitman 2007). To Tocqueville, society's level of orderliness, functionality, and prosperity did not primarily depend upon the omnipresent threat of observation or incarceration. Social order was instead more dependent upon a "delicate art of civil association" (Tocqueville 1990b, 895). Though subtle, this

\footnotetext{
${ }^{10}$ Smith's (2009, 544-590) early reliance on comparative analytics can be seen in his continual juxtapositions relating England to France with regard to policing.
} 
core insight of Tocqueville's broader social theory is fully intact, albeit less developed, within the earlier and more hastily drafted prison report. Verbal communication and social interaction are the key factors separating the different outcomes across the three core prison models surveyed therein. ${ }^{11}$

Individualists, as philosophers of political economy, were active in policy debates, ${ }^{12}$ but their main focus within such discussions was usually the institutional differences across social contexts. Given the universal features of human decision-making, public policies need to be framed in general terms in order to be effective across varied environments (Hayek 1960, 149). ${ }^{13}$ As Hobbes (1996) correctly noticed, when societies cannot mitigate violent conflict they cannot develop. When they cannot enforce property rights and contracts they cannot prosper. Some communities succeed at these challenges better than others. Hobbes believed centralizing state authority was a necessary precondition for social order. Classical individualists did not emphasize the superior enforcement capacities of a particularly centralized regime, but instead highlighted how certain institutions incentivize the social processes of production, innovation, and adaptation therein better relative to others. ${ }^{14}$ True, violent conflict was a significant barrier to initial social development, but punitive variance simply cannot account for the patterns of wealth observed in the industrial and post-industrial

\footnotetext{
11 "[w]hy are these nine hundred collected malefactors less strong than the thirty individuals who command them? Because the keepers communicate freely with each other, act in concert, and have all the power of association; whilst the convicts separated from each other, by silence, have, in spite of their numerical force, all the weakness of isolation" (Bauemont and Tocqueville 1968, 26).

${ }^{12}$ Mill (1869) was an early advocate for women's suffrage and opposed capital punishment. Beccaria (1995) expressed strong opposition to torture as a means of interrogation, and Smith (2009) supported habeas corpus as a constraint against excessive monarchical power.

${ }^{13}$ Boettke, Coyne, and Leeson (2003) would imply natural language methods are explicitly needed to recognize these forms of generalizable social processes. Weber (1946) referred to the analytic role of human intentionality as verstehen (literally translated 'meaning'), a useful parallel to Hayek's 'reason'. Mises (1957) distinguishes pure historicist descriptions of human behavior from praxeological accounts. The pure historian, akin to pure economist, does not assess the normativity of her subject, nor does she presume phenomena to be governed by singular or external control. Praxeological accounts, on the other hand, insist upon the presumption that agents define their various purposes subjectively.

${ }^{14}$ Here again Smith's $(1982,544-590)$ comments on policing are most revealing as the vast majority of the text is dedicated to describing the functions of the division of labor rather than detailing formal enforcement efforts per se. In Smith's view, a peaceful social environment is most dependent upon a general condition of prosperity and legal equality across citizens to engage in trade-not necessarily a superior strategy of law enforcement.
} 
economies (Boettke, Caceras, and Martin 2012). Political authorities are purposeful and adaptive as well. When afforded the choice, political leaders will select those enforcement policies and technologies that they perceive to best promote their interests, which are not necessarily identical to the public welfare.

When township populations first grew into formal political citystates, ruling authorities found public and corporal punishments useful tools for deterring crime and promoting social order. Prior decentralized and customary legal systems were largely self-enforcing. ${ }^{15}$ Theft and fraud were suppressed without state-sponsored punishments, because potential criminals feared being denied access to market spaces and legitimate courts. ${ }^{16}$ As populations grew, the probability of any individual being detected and brought to trial waned. The severity, frequency, and/or publicity of penalties grew in part to maintain deterrence from crime, but also to promote compliance, retain authority, and expand political power. Goebel (1937) and Benson (1992) suggest the historical prohibition of customary feuds and self-serving violent enforcements complemented state interests for greater abilities to tax, regulate, conscript, and avoid insurrection. Without the enforced threat of exile, outlawry, or legitimate retaliation, the incentives for crime grew. ${ }^{17}$ The transition from isolated American colonies to formal states under the later federalist system was a similar transition from decentralized autonomous units, to more formalized state powers (Rothman 1971).

State sponsored, physically corporal, and publically visible punishments such as scaffolding and flogging signaled severe costs to criminal behavior across later growing populations, hence they simultaneously increased deterrence while supporting authority power, but only to a point (Foucault 1975; Moskos 2011). Tolerance for violent

\footnotetext{
${ }^{15}$ Maine (2013) explains the lack of a state-defined criminal law is a common feature across ancient legal systems. Hoebel (2006) reports similar findings in more contemporary tribal contexts. Hume (2005, 484-501), Menger (1994), Demsetz (1967), Posner (1980; 1981), Johnsen (1986), Baden, Stroup, and Thurman (1981), and Benson (1988; 1989) all explain the development of property rights and contract enforcements as a spontaneous process ancillary to state design.

${ }^{16}$ Olson $(1971,1982)$ argues costs of isolated anarchic living were an impetus behind serfdom organizational forms in early city-states. Sources listed in footnote 15 all describe the effects of customary norms such outlawry, familial feuding, exile and death penalties as sufficient mechanisms for inducing compliance to person and property rights norms and court procedures within earlier legal systems.

${ }_{17}$ Benson (1992) surveys a wide swath of legal historians whom all confirm that criminal law developed later than civil law.
} 
spectacles diminished as they were applied to relatively arbitrary sanctions amidst growing proprietary crime rates (Tobias 1979; Beattie 2001; Berman 2006, 606-629). Publically financed and managed police and prison systems renewed deterrence, appeased puritanical preferences for humane alternatives to scaffolding, and served authority interests in both the British and US context. ${ }^{18}$ They also represented a newly concentrated interest in the development and application for dedicated, formalized, and quantitative social science of crime and punishment.

Momentum towards centrally planned criminal justice was further buttressed by quantitative methods of criminal sentencing and applied punishments. ${ }^{19}$ Constructivists thought that social order and progress were impossible without the guiding influence imposed by designed legal systems. Hayek (1948) quotes Descartes (1999), explicitly referencing criminal legislation:

[...] nations which, starting from a semi-barbarous state and advancing to civilization by slow degrees, have had their laws successively determined [...] by experience of the hurtfulness of particular crimes and disputes, would by this process come to be possessed of less perfect institutions than those which [...] have followed the appointment of some wise legislator (10-11).

Bentham (2010) similarly writes:

[...] a man may pretend to abjure their empire: but in reality he will remain subject to it all the while. The principle of utility recognizes this subjection, and assumes it for the foundation of that system, the object of which is to rear the fabric of felicity by the hands of reason and of law $(14$, italics in original).

Constructivists early noticed a tension between the subjective nature of crime and the practical desires for regimented punishments. ${ }^{20}$

\footnotetext{
${ }^{18}$ Elias (1969), Gatrell (1980), and Pinker (2011) have all tracked a substantial decline in inter-personal and privately motivated violence in the modern era and amidst the rise of more formally defined and empowered nation states.

${ }^{19}$ Caldwell (2010) notes "[Wesley Claire] Mitchell concluded that the Philosophical Radicals [such as Bentham] were successful in pushing through certain [penal] reforms not because of their theories of human nature [...] but because their ideas matched up well with the sorts of changes that powerful, interested parties already favored" (21).

${ }^{20}$ Allen (1999) explains how observed inequality inspired more state involvement in criminal justice processes in Ancient Greece. Abramson (2000) argues similar rulings regarding minority cases in part jeopardized the robust principles of American court processes in the wake of New Deal overhauls during the 20th century.
} 
Bentham (2010) described the philosophical standard of proportionate punishment as "oracular" more than "instructive" because "[t]he same nominal punishment is not, for different individuals, the same real punishment" (32). Penalties could encourage rather than deter criminal behavior if not gauged optimally. If more severe crimes do not earn more severe penalties, to the extent that criminals gain utility from their crimes, they are, in effect, inclined to commit a more severe offense $(140-146){ }^{21}$

The panopticon (Bozovic 1995) was designed not only as a punitive tool for gauging criminal sentences but also as an elaborate scheme of social engineering.

Morals reformed-health preserved-industry invigoratedinstruction diffused-public burthens lightened-Economy seated, as it were, upon a rock - the Gordian knot of the Poor-Laws are not cut, but untied - all by a simple idea in Architecture (31)!

Little regard was paid to the individualists' observations that enforcement regimes varied according to local conditions.

"No matter how different, or even opposite the purpose: whether it be that of punishing the incorrigible [...] curing the sick [...] or workhouses [...] It is obvious that, in all these instances, the more constantly the persons to be inspected are under the eyes [...] the more perfectly will the purpose of the establishment have been attained" (34).

Johnston (2000) notes almost every developed nation of the time sent investigators to report the logistics and effects of newly designed, built, and managed American penitentiaries. Many such facilities were direct recreations of Bentham's panopticon design with central observational towers and surrounding circular amphitheaters of inmate cells, others merely shared the general observational principles of panopticism but leveraged larger floor plans via central observational hubs with spokes of hallways laid out therefrom (Rubin 2013). Facilities were mimicked and constructed throughout the developed world within decades. Incarceration has been the standard form of criminal penalty since. ${ }^{22}$

\footnotetext{
${ }^{21}$ Such is a particularly early recognition of the third law of demand (Alchian and Allen 1964).

${ }^{22}$ See Rothman (1980), McConville (1995), O'Brien (1995), Morris (1995), and Rubin (2015).
} 
Foucault (1975) argued prisons, though couched in humane rhetoric, secluded punishment from the effective constraint of public oversight. Hence, incarceration galvanized state power and opportunities for corruption. Staff and wardens faced logistic challenges to maintain the conditions of panopticism: isolation and continual observation. Early reports describe harrowing facilities and dehumanizing practices (Spierenburg 1991; Canuel 2007; Geltner 2008). While prison architecture aimed for rehabilitation and social improvement, real prison management required hoods, shackles, physical deprivations, violence, and intimidation to continuously suppress social cooperation and communication amongst inmates. Prisons supposedly incapacitated criminals from harming society, but facilities were designed and managed to suppress any semblance of social community within their walls. Such sites were dystopian settings, antithetical to the artful forms of civil association explained by Tocqueville (1990). Similarly, Rothman (1971) documents how New Deal spending drove prison constructions throughout America thereafter. In effect, displacing civil institutions previously evolved to serve the social needs of security, rehabilitation, and monitored living. ${ }^{23}$

According to Putnam (2001), the latter 20th century endured significant declines of social capital, via fewer civic organizations, and weaker informal institutions. Many of these institutions were dedicated to social functions such as poverty assistance and healthcare (Cornuelle 1965; 1983; Beito 2000). Rothman (1971) explains similar displacements reshaped the social provision of public safety and criminal justice as early civic groups and organizations played major roles in securing persons and property, and facilitated reputational norms for criminal deterrence and rehabilitation prior to the New Deal. Inversely, during the latter half of the 20th century federally managed and financed criminal justice bureaucracies experienced multiplicative growth (Stephan 2004; Kyckelhahn 2012).

Some early members of a structural functionalist tradition, writing on American investigations at the beginning of the 20th century, shared the natural language methods and universalizing features of human behaviors as the individualist classical school (Reimer 1937; Schrag 1944; Clemmer 1958; Sykes 1958; Cloward et al. 1960; Irwin and Cressey

\footnotetext{
${ }^{23}$ See also Sellin (1931), Friedman (1994), and Meskell (1999).
} 
1963). ${ }^{24}$ Inmate populations were a unique opportunity to study human actions and community dynamics in a closed environment over long periods of time. Inmates were seen as purposeful agents and their social bonds and inter-personal relationships served important functions in maintaining order and promoting collective goals, but such required an intimate and theoretically informed vantage to recognize and understand. Sykes (1958) writes, "[w]e must see the prison as a society within a society [...] prisons appear to form a group of social systems differing in detail but alike in their fundamental processes, a genus or family of sociological phenomena" (xxx-xxxi).

For Sykes, the unique societies within prisons functioned and maintained order in so far as the policies of prison managers effectively harmonized with the schemes of informal norms that organically developed amongst inmates. If policies controlled inmate conditions sufficiently to suppress escapes while also coordinating the incentive patterns of inmates, peace prevailed. If policies were instead too tyrannical, inmates were likely to revolt. He explains features of the prison riot in terms similar to Smith's $(2009,212)$ "man of systems", Sykes (1958) writes, "many individuals bound together for long intervals. Such aggregates enduring through time must inevitably give rise to a social system-not simply the social order decreed by the custodians" (xxx).

Over time, more prison facilities were built and operated throughout American cities and states, many larger and less amenable to relatively laissez faire models of inmate compliance as Sykes proscribed. Wardens in larger facilities sought uniformity and standardization as criminal justice standards homogenized across states and jurisdictional boundaries. In time, the structural functionalist tradition declined in prominence, as professional and political standards preferred more technical and quantitative methods. As Sykes $(1958,138)$ explains such "was closely linked to the growth of federal funding for the scientific research".

\footnotetext{
${ }^{24}$ Goffman (1957) was an exception to the individualist aspect of the functionalist tradition, as he tended to emphasize the pervasive and/or permeating influence of prisons and asylums as 'total institutions'. He shares common ground in our model with other functionalists given his use of natural language over quantifiable empirics.
} 


\section{THE POSITIVIST SCHOOL}

As a product of the 19th century, the positivist school maintained a presentation of natural language methods compatible to and generally similar to the analytical presentations of classical thinkers. Where positivism differed substantially, was its commitment to universalist understandings of human behavior-or lack thereof. Whereas classicals sought to fit their understanding of crime and punishment within a consistent paradigm of human agency, positivists held no such commitments. Positivists were in effect early adherents to scientism in so far as they prioritized the measurement and testability of social propositions over a consistent understanding of purposive agency or human intentionality. Criminals and criminal behavior were first recognized as an object of inquiry for their obvious social consequences, but viewed as totally distinctive from normal and/or legitimate individuals and behaviors. Positivist research was motivated by questions such as: What are criminals? What measurable factors contribute to crime, and by what empirical proxies can we gauge and improve the effects of punishments?

Prison construction and operation expanded throughout the developed world amidst the 19th century. As inmate populations grew in size and frequency, they drew increased attention from social scientists and thus the perspectives of the classical political economists and individualist wing of the functionalists held less sway. Prison managers sought to better manage their facilities, control the populations therein, compel inmate labor, and suppress rebellions. Wardens developed theories of inmate behavior and sought out useful frameworks for prison management and population control. Prison authorities accommodated social scientists' requests to observe and investigate the newly contained samples of social organization. The positivist school found prisons ideal for quantitative data collection. Inmates were confined, easily observed, required to answer surveys, and could be tracked consistently over time. The question remained, what precise datum should investigators measure and track?

Convinced that criminal behavior had biogenetic causes, Lombroso (1911) measured and tracked inmate's physical traits and characteristics such as sloping foreheads, hair color, eye and lip shape, and facial symmetries. He quickly noticed that, relative to the general population, inmates more often possessed scars, asymmetric features, and a variety of so-called abnormal or deformed traits. 
[T]he distinction between the criminaloid, the occasional criminal, the criminal by passion, and the born criminal, as well as the study of the more important causes of crime, enables us to determine with precision the individuals to whom we can apply our curative processes, and the method appropriate to each case (xxxiii).

Given the inherent challenge to social science posed by subjective bias, social theorists long sought consistent and quantifiable forms of behavioral measurement. The scarcity and rarity of data shaped the focus and direction of research through time. Homing in on tangible physical factors complemented public policy attitudes desiring proven and targeted responses to the social problems that came with criminal behavior. When in fact, studies informed and motivated by abundant data may be biased representations of real history. An observed commonality across physical characteristics of inmates is not necessarily support for a genetic causation of criminal behavior. For one counterpoint, early violent routines of arrest and punishment contributed to physical abnormalities observed in prisons (Foucault 1975). Bad science has a greater opportunity to arise and an easier time sustaining itself amidst a professional and political culture of scientism.

In hindsight, positivist criminology demonstrates an obvious flaw to blind insistence for quantification. Such scientism directly spawned eugenic proposals for sterilizations, insulated authoritative political theories of ruling birthrights, and drew out complicity regarding psychophysical forms of rehabilitation such as genital mutilation (Hamowy 1977) and electroshock therapy. Peart and Levy (2005) explain that eugenics, like all central-planning schemes, was subject to unintended consequences and corruption by ruling interests. Hence there is more at play than just bad science fostered through hateful prejudice. Such bad science can instead be seen as a direct consequence of methodological biases. Criminological positivism and its eugenic policy implications conveniently serviced the professional and political standards of formal modeling and quantifiable measurement, but at the cost of obviously more foundational social demands for fairness and justice.

A later, second branch of positivism (Ferri 1996; 2004; Lacassagne 1891) saw the dominant causes of crime explained by measurable social, rather than biophysical, factors. Inmates shared similar family histories such as being orphaned and/or violently abused. More attune to human intentionality and purposefulness than Lombroso, the social wing of the positivist school still obsessed for quantification and statistical 
predictability. Influenced by Durkheim (1997; 1982), later positivists perceived crime and social processes as direct results of social structures. Ferri (1996) wrote, "[e]very physical phenomenon is the necessary effect of the causes that determined it beforehand" (35).

In so far as positivists believed social structures were the ultimate cause of criminal behaviors, the organization of social institutions bore the moral responsibility for the harms caused by crime in society.

The social environment is the breeding ground of criminality; the germ is the criminal, an element which has no importance until the day where it finds the broth which makes it ferment [...] Justice shrivels up, prison corrupts and society has the criminals it deserves (Lacassagne 1891, 364).

Puritanical motivations for corporal rehabilitations such as isolation and flogging, and spectacular deterrence techniques such as scaffold hangings were displaced as rehabilitation's psychotherapeutic intentions to form as a wide swath of experimental conditions imposed on inmates. Several commentators note the coeval institutional histories of prison facilities and insane asylums, especially in America during the 19th and 20th centuries (Foucault 1964; 1975; Rothman 1971; 1980; Szasz 1973).

Neither biological nor sociological positivists could explain patterned changes in crime and punishment as time passed. Why do periods experience more or less crime systematically without significant biological or sociological changes?

The honest historicist would have to say [...] All we believe to know is how similar policies worked in the past. Provided all relevant conditions remain unchanged, we may expect that the future effects will not widely differ from those of the past (Mises 1957, 203).

By the mid 1970s many studies had attempted to track the effectiveness of rehabilitation strategies ranging a wide gamut including spectacular corporal, psycho-punitive, psycho therapeutic, pharmacological, and behavioral counseling. Martinson's (1974) survey concluded bluntly: nothing works! Not only were criminals apparently no less likely to commit crime upon release, but recidivism rates-the frequency that released criminals re-offend-continuously rose despite growing support and funding for criminal justice institutions (Lipton, Martinson, and Wilks 1975). 


\section{The ChICAgo SCHOOL}

Shaw and McKay (1942) arguably provided the foundations for the Chicago school approach to criminology on compatible methodological grounds to the classical approach. Their work utilized comparative analytics to recognize how socio-conditional factors related to local community performance. Educational and employment opportunities were critical to shaping criminal trends amongst juveniles.

Much like how functionalists across ideological camps (Grossman and Sykes alike) gave way to more empirical academic and political standards, demands for formal modeling and quantitative measurement quickly rebranded the Chicago school into more econometric forms. These latter approaches proved more appealing to 'tough on crime' policy efforts.

In the midst of rising crime and shaken support for the rehabilitation paradigm, Becker (1968; 1974) and Wilson (1975; Wilson and Herrnstein 1985) re-introduced a formalistic rational-choice approach to crime and punishment. Parallel to the classical view, rational criminals commit less crime when the costs of criminal behavior are high and the expected returns low. By increasing the severity and/or the probability of punishment, the quantity of criminal behavior should-other things constant-decline. Formal police budgets represented an obvious and tangible proxy for adjusting the probabilities of catching criminals, while prison sentences similarly served as a tangible means to gauge the severity of punishments and fine-tune social incentives away from crime.

Unlike the rational choice approach of the classical school, Chicago scholars replaced natural language methods with formal mathematics. Combined with newly gathered and already available data, the rational model of crime and punishment formulated hypotheses testable against real evidence. Ehrlich (1972) measured deterrence from punishment ratcheting. ${ }^{25}$ The data agreed with the logic and struck hard against earlier sociological and psychological perspectives. Whereas the rehabilitation paradigm posited social responsibilities for crime; the Chicago approach modeled criminal agents as volitional and calculative

${ }^{25}$ See also Ehrlich $(1975 ; 1977 ; 1981 ; 1982)$. 
in their decision-making, thus complementing the rise of retributive philosophies and tough on crime policies. ${ }^{26}$

Significant debates followed Becker's and Ehrlich's works. ${ }^{27}$ Beyleveld (1982) accused Ehrlich of imposing a formalized version of rationality upon all criminal behaviors equally. Cameron explains, similarly, "all individuals obey the same calculus and even have the same utility function, which is unchanging over the life cycle" (1989, 32). Such fit Hayek's (1952) descriptions of scientism, "before it has considered its subject, claims to know what is the most appropriate way of investigating it" (Hayek 1952, 24). Hayek further quotes Bridgeman (1928) explaining scientisisms tendencies "to postulate that all possible experience conforms to the same type as that with which we are familiar" (46). Ehrlich's (1982) response concedes to the minimal standards of policy relevance when he writes, "for the theory to be useful in explaining aggregate behavior, it is sufficient that a significant number of the 'marginal offenders' conform with this hypothesis" (126127).

Formal hypotheses require specification and often simplification to be testable. Which deters more: longer prison stays or capital punishment? Ehrlich's empirics show a significant and consistent correlation between applied capital punishments and lower violent crime rates. Such demonstrates that under past institutional conditions capital punishment deterred more strongly against violent crime than incarceration. While execution offers obvious financial savings over incarceration (Friedman 1999), Ehrlich's research does not inherently imply policy support for more executions. It does not follow from Ehrlich's approach that capital punishment is universally efficient or socially optimal. More narrowly, capital punishment seems to provide cost savings given current institutions. There may be better solutions, perhaps infinite possibilities, but they are unknown and often require forms of social experimentation and institutional evolution akin to classical descriptions.$^{28}$ Furthermore, despite such research not carrying

\footnotetext{
${ }^{26}$ Mundle (1969), Davis (1972), and Kleining (1973) represent the key moral arguments in favor of desert inspired retributive justice.

${ }^{27}$ Critics include but are not limited to Baldus and Cole (1975); Bowers and Pierce (1975); Passell (1975); Friedman (1979); Pasell and Taylor (1976; 1977); Blumstein, Cohen, and Nagin (1978); and Barnett (1978).

${ }^{28}$ One example is Friedman (1989), who argued that the profit motives of private enterprise if applied to the provision of law and order could increase the real term efficiency of crime prevention and detection.
} 
the direct policy implications that capital punishments represent an efficient norm over alternatives or that tougher punishments ought to be imposed relative to viable alternatives, policy makers and strategic campaigns effectively capitalize on such findings as support for tough on crime proposals nonetheless.

One must presume incarceration is an efficient form of punishment if one is to try and economize on prison space via mathematical modeling (Avio 2003). Policy makers treat status quo police, courts, and prisons as components of a presumably effective institutional black box. When it is accepted that increasing the costs of crime deters criminals, punishment acts as a cost, and incarceration is the assumed technique, it follows that in times of high crime, the policy response is more and tougher police, longer and more frequent punishments, and the building of more prisons. Though a variety of early theory and empirics consistently demonstrated the larger impact from changing the probabilities rather than the potencies of punishments, political authorities tended to view the new Chicago research stream as a mandate for tougher sentencing laws and increased criminal justice budgets nonetheless (Harcourt 2011).

Forms of non-pecuniary utility do not fit well within the formal calculus of mathematical models. Real people consider concepts such as fairness, liberty, and equality before the law seriously when assessing the qualitative features of criminal justice systems and other social institutions. Benson (2003) explains technological efficiency is not synonymous with economic efficiency. Ehrlich admits "there would be a range of alternative enforcement instruments with a deterrent potential that could be brought to bear in an effort to achieve a desirable degree of crime prevention" $(1982,137)$. But the incentives for discovering those alternatives are altered by public subsidy whereas police enhancements and prison expansions conveniently appease and service status quo and ever growing interest groups. In result, those frameworks, with quantifiable data and precise statistical predictions were most preferred and subsidized by increasingly centralized and federally managed criminal justice bureaucracies amidst the American 20th century experience.

\section{MODERN RESEARCH ON CRIME AND PUNISHMENT}

Social science research on the topics of crime and punishment in the latter 20th and early 21st centuries has been dominated by formal 
methodologies. Again, in contrast to the classical school, modern projects were not seeking to provide a universal theory of crime nor a consistent rationale for punishment. By nature of such formalism and the advanced standards of better science, contemporary research is more often constrained in application to particular times and places. This methodological trend seems less subject to pernicious forms of political capture compared to previous instances of scientism and perhaps possesses more opportunities for comparative analyses. Contemporary topics cover more narrowly framed questions such as why did crime rates decline so unexpectedly (DiIulio 1996) in the US during the 1990s? Or, what accounts for the exceptional increase in US incarceration rates?

The explanations are varied, sometimes contradictory, debated, and remain unsettled. Blumstein and Beck (1999) repeat the insights of the Ehrlich debates when they explain that the probability of being incarcerated once arrested has doubled since the 1980s, while arrests, sentence lengths, and guilty verdicts have all remained relatively constant. Donohue and Levitt (2001) hold that increased incarceration partly explains the recent crime decline, but Levitt (1996) also shows prison overcrowding can have a hardening effect on inmates, driving crime up instead of down. Again, universal implications or generalizable insights are less discernable from these current streams of research as they are framed in comparably narrow terms to the earlier historicists.

Data availability and empirical techniques have radically improved since the days of the positivist school and should rightly be distinguished therefrom. For example, a vibrant field of research exists at the intersections of neuroscience and criminology (Glenn and Raine 2014). One might inappropriately rush to infer similar policy intentions as the positivists of old. If crime has genetic origins, apart from genetic selection, what can be done? Thankfully, broader social conditions simply do not tolerate anything likening to eugenics. Contemporary neuroscientists should be given the charitable interpretation that they pursue knowledge within some minimally presumed political commitment to contemporary standards of justice and fairness (Broer and Pickersgill 2015). Scientism is not all-powerful. But, while bad science has been displaced by much better techniques, scientism's expression in the criminal justice arena is in part mitigated by its expression in other policy arenas. Given surrounding social standards of equality and justice, neurological origins of criminality are perceived 
and translated into political opportunities for expanding educational and mental health resources. Only time will tell the impacts and efficacies of such reactions.

Furthermore, newer studies of crime and punishment often do not directly imply any particular policies, to a significant degree because there is now a widespread recognition that real crime rates are largely separable from public policies. Research into the linkages between various empirical factors with criminal behavior must more narrowly define crime types than in the past, as criminal prohibitions have widely expanded. Asking what contributes to criminal behavior today is very different from asking the same question one hundred or two hundred years ago, if only because the criminal code is much more expansive today. Hence, today's empiricism tends to focus on more narrowly individual crime types such as violent behavior.

General trends in violent and/or property crimes are beginning to be re-recognized as outcomes of a complex set of interacting variables and incentives. Kleiman (2009) and Gladwell (2002) for example, explain well that the contributors to declined crime are multi-faceted, subtle, and often seemingly unrelated to formally designed criminal justice institutions. ${ }^{29}$ Arguably, crime is more complex than traditional institutions can hope to perfectly regulate or control, and hence more complicated than static modeling techniques can hope to fully capture.

Boettke, Coyne, and Leeson (2003) argue great potentials exist to bridge the methodological gap between the formalistic and particular (fourth vision-upper left quadrant of figure 1) contemporary economics and the universal natural language (first vision-bottom right quadrant of figure 1) of the classical approach. Similar potentials can be seen across such methodological approaches to crime and punishment. Amidst the new appreciation of crime and punishment as complex social phenomena have arisen a number of obviously fascinating topics for social science. What are the industrial dynamics of organized crime? What explains the successful cooperation and collective actions observed in historic examples of large-scale criminal endeavors? How do we explain the rise, internal operations, and industry wide dynamics of drug trafficking organizations and prison gangs? Such questions simply do not lend themselves to formal modeling and quantitative analytics.

${ }^{29}$ For example, Lott (1998) tracks increased gun ownership, Benson (1998) and Benson and Mast (2001) show census data on new private security investment, and Rizzo (1980) explains that even minor decisions like taking a taxi can be conceptualized as anti-crime investments. 
Data on illicit trades and behaviors is inherently more difficult to gather and assess, though these questions are socially prescient and command scholarly attention nonetheless. Hence, the culture of scientism, may sow the seeds of its own destruction because the greater marginal returns associated with resolving challenging and complex subjects attracts methodological innovators.

Various scholars leverage heterodox techniques to peel back the professional and political orthodoxies that previously obstructed compelling research. Retaining the basics of formal modeling, Buchanan (1972) argued the socially efficient level of organized crime was conceptually greater than zero, as mafias akin to traditional monopolies increased prices and restricted output. Leveraging more intensive and ethnographic case study approaches, Reuter (1983) noticed competitive equilibriums when prohibitions impede illicit operations from exploiting economies of scale. Most recently, Gambetta (1996; 2011), Leeson (2009), and Skarbek (2014) have provided detailed accounts of how organized criminal outfits innovate constitutions to provide governance within their ranks, maximize profits, and evade punitive enforcements. Such work is in a way re-discovering the comparative institutional techniques and insights of the classical school by beginning from a broad swath of quantitative and qualitative case studies and applying universal concepts of rationality and profit-driven actions. Again, time will tell if such methodological innovations can re-direct scientism's past influences upon criminal justice policies and outcomes.

\section{CONCLUSIONS}

Prison architectures and the practices of incarceration were designed to accomplish philosophically abstract intentions such as rehabilitation and the promotion of social order. Those aims proved difficult and at times impossible given practical limitations and resource scarcities (Feeley and Simon 1992). Though prison facilities and incarceration did prove convenient for the enforcement of certain social engineering regimes, prohibition efforts, and regulatory controls. The promises of Bentham's (1907) panoptic architectures, to resolve the calculative challenges of punishments and promote social order via precise incentives, were quickly benchmarked and replicated around the world. Positivism allowed for both the eugenics movement and the various forms of corporal rehabilitation deployed throughout the 20th century. Chicago-style modeling well-served the political platforms to 'get tough 
on crime'. Lastly, individual criminological case studies accumulated while enforceable regulations and prohibition resources grew in size and complexity by orders of magnitude.

Micro-sociological accounts of the prison experience reveal practices and conditions commonly perceived as inhumane (Rhodes 2004). Facilities are designed to suppress both the individual and social features of the human condition. The technologies of confinement, doors, fences, lights, food service, healthcare, and recreation are subjected to automation, isolation, and perpetual observation. Amidst fiscal constraints, even if dirigiste proposals for rehabilitation were effective, they are simply not optimal from managerial perspectives. Contemporary prisons cannot meaningfully be considered penitentiaries, reformatories, or houses of correction. Today's incarceration is a process of warehousing human beings amidst bureaucratic incentives. In result, such processes are not substantially different from the warehousing of standard commodities or livestock. ${ }^{30}$ In so far as such practices affect the relative balances of power in society, criminological sciences are amidst a process of abused reason.

Hayek's methodological theory of social change would suggest these a-rationalities of America's criminal justice stem in part from the methodological trends in the fields of social science attended to crime and punishment. The production of scientific research endures processes of creative destruction. Changes in the relative availabilities of data and research technologies reflective of contextual political and professional interests inspire changes in dominant theory. Through history, bureaucratic incentives favored formal methods in so far as they accommodated central planning efforts, desires for quantifiable analysis, and preferences for statistical forecasting. In particular, criminal punishment by means of penal incarceration was complemented by specific economic and criminological social theories. Significant and effective penal reform today may require changes in the dominant methods used in criminological social science.

\footnotetext{
${ }^{30}$ Garland (2001) writes, "[i]mprisonment has emerged in its revived reinvented form because it is able to serve a newly necessary function in the workings of late modern, neo-liberal societies: the need for a 'civilized' and 'constitutional' means of segregating the problem populations created by today's economic and social arrangements" (199). Wacquant (2009) similarly notes "incarceration serves to physically neutralize and warehouse the supernumerary fractions of the working class and in particular the dispossessed members of stigmatized groups" (xvi). Alexander (2010) parallels the structural influence of mass incarceration upon American blacks as akin to a new Jim Crow era.
} 
In the decades since the late 1970s America's criminal justice resources arguably became unreasoned. Pecuniary costs (Bauer and Owens 2004), enforcement techniques, ${ }^{31}$ and the demographic make up of incarcerated populations (Aladjen 2008; Loury 2008; Brown 2009; Wacquant 2009; Alexander 2010), did not correspond to the structural magnitudes of crime rates, nor democratic measures of public opinion (Walker and Hough 1988; Flanagan and Longmire 1996). American criminal justice was disproportionate relative to other times and comparable nations (Pease 1992; Sutton 2004; Cavadino and Dignan 2006; Tonry 2007; Lacey 2008; Walmsley 2003). Several described these trends as inefficiently severe and unsustainable (Becket 1997; Garland 2001; Roberts et al. 2003; Whitman 2003; Moskos 2011). Higgs (2004) bluntly explained at the height of the trend,

[...] if the total incarcerated population were to continue to grow by 7.3\% annually, it would double approximately every ten years [...]. Hence, in the decade of the 2080s, within the lifetime of many people already born, the prison population would overtake the total population (96).

In summary, a strong inter relationship can be discerned between the methodological trends of social science dedicated to crime and punishment on the one hand, with real policy trends and social outcomes on the other. As luck would perhaps have it, our processes of supposed systemic failure have presently stagnated amidst a similar proliferation of newly diversified research streams rekindling an attempt to situate crime and punishment studies into a consistent model and understanding of human social order.

\section{REFERENCES}

Abramson, Jeffrey. 2000. We the jury: the jury system and the ideal of democracy. Cambridge (MA): Harvard University Press.

Aladjem, Terry. 2008. The culture of vengeance and the fate of American justice. Cambridge: Cambridge University Press.

Alchian, Armen, and William Allen. 1964. University economics. Belmont: Wadsworth.

Alexander, Michelle. 2010. The new Jim Crow: mass incarceration in the age of colorblindness. New York: New Press.

Allen, Danielle. 1999. The world of Prometheus: the politics of punishing in democratic Athens. Princeton: Princeton University Press.

\footnotetext{
${ }^{31}$ See Garland (2000, 349-350) for an explanation of the broad concept of contemporary increased punitive severity.
} 
Avio, Kenneth. 2003. The economics of prisons. In Changing the guard: private prisons and the control of crime, ed. A. Tabarrok. Oakland: Independent Institute, 9-56.

Baden, John, Richard Stroup, and Walter Thurman. 1981. Myths admonitions and rationality: the American Indian as a resource manager. Economic Inquiry, 19 (1): 399-427.

Baldus, David, and James Cole. 1975. A comparison of the work of Thorsten Sellin and Isaac Ehrlich on the deterrent effect of capital punishment. Yale Law Journal, 85 (2): $170-186$

Barnett, Arnold. 1978. Crime and capital punishment: some recent studies. Journal of Criminal Justice, 6 (4): 291-303.

Bates, Robert, Avner Greif, Margaret Levi, Jean Rosenthal, and Barry Weingast. 1998. Analytic narratives. Princeton: Princeton University Press.

Bauemont, Gustave, and Alexis de Toqueville. 1968 [1833]. On the penitentiary system in the United States, and its application to France: with an appendix on penal colonies. New York: Augustus M. Kelley Publications.

Bauer, Lynn, and Steven Owens. 2004. Justice expenditure and employment in the United States, 2001. Bulletin NCJ 202792, Washington: United States Department of Justice, Bureau of Justice Statistics.

Beattie, John. 2001. Policing and punishment in London, 1660-1750: urban crime and the limits of terror. Oxford: Oxford University Press.

Beccaria, Cesare. 1995 [1764]. 'On crimes and punishments' and other writings. Cambridge: Cambridge University Press.

Becker, Gary. 1968. Crime and punishment an economic approach. Journal of Political Economy, 76 (2): 169-217.

Becker, Gary. 1974. Law enforcement, malfeasance, and compensation of enforcers. Journal of Legal Studies, 3 (1): 1-18.

Beckett, Katherine. 1997. Making crime pay: law and order in contemporary American politics. Oxford: Oxford University Press.

Beito, David. 2000. From mutual aid to the welfare state: fraternal societies and social services, 1890-1967. Chapel Hill: University of North Carolina Press.

Benson, Bruce. 1988. An institutional explanation for corruption of criminal justice officials. The Cato Journal, 8 (1): 139-163.

Benson, Bruce. 1989. Enforcement of private property rights in primitive societies: law without government. Journal of Libertarian Studies, 9 (1): 1-26.

Benson, Bruce. 1992. The development of criminal law and its enforcement: public interest or political transfers. Journal des Économistes et des Études Humaines, 3 (1): 79-108.

Benson, Bruce. 1998. To serve and protect: privatization and community in criminal justice. New York: New York University Press.

Benson, Bruce. 2003. Do we want the production of prison services to be more 'efficient'? In Changing the guard: private prisons and the control of crime, ed. A. Tabarrok. Oakland: Independent Institute, 163-216.

Benson, Bruce, and Brent Mast. 2001. Privately produced general deterrence. Journal of Law and Economics, 44 (2): 725-746.

Bentham, Jeremy. 1907 [1789]. An introduction to the principles of morals and legislations. Oxford: Clarendon Press. 
Bentham, Jeremy. 2010 [1780]. The rationale of punishment. Honolulu: University Press of the Pacific.

Berman, Harold. 2006. Law and revolution II: the impact of the protestant reformations on the western legal tradition. Cambridge (MA): Harvard University Press.

Beyleveld, Deryck. 1982. Ehrlich's analysis of deterrence: methodological strategy and ethics in Isaac Ehrlich's research and writing on the death penalty as a deterrent. British Journal of Criminology, 22 (2): 101-123.

Blomquist, William. 1992. Dividing the waters: governing groundwater in southern California. San Francisco: ICS Press.

Blumstein, Alfred, and Allen Beck. 1999. Population growth in U.S. prisons, 1980-1996. Crime and Justice: A Review of Research, 26: 17-61.

Blumstein, Alfred, Jacqueline Cohen, and Daniel Nagin. 1978. Deterrence and incapacitation: estimating the effects of criminal sanctions on crime rates. Washington D.C.: National Academy Press.

Boettke, Peter, and Paul Aligica. 2009. Challenging institutional analysis and development: the Bloomington school. Abingdon-on-Thames: Routledge.

Boettke, Peter, Christopher Coyne, and Peter Leeson. 2003. Man as machine: the plight of 20th century economics. Annals of the Society for the History of Economic Thought, 43 (1): 1-10.

Boettke, Peter, Zachary Caceras, and Adam Martin. 2012. Error is obvious, coordination is the puzzle. In Hayek and behavioral economics, eds. R. Frantz and R. Leeson. Basingstoke: Palgrave-MacMillan, 90-110.

Bowers, William, and Glenn Pierce. 1975. The illusion of deterrence in Isaac Ehrlich's research on capital punishment. Yale Law Journal, 85 (2): 187-208.

Bozovic, Miran (ed.). 1995. Jeremy Bentham: the panopticon writings. Edinburgh: Verso.

Brennan, Geoffrey, and James Buchanan. 2000 [1985]. The reason of rules: constitutional political economy. Indianapolis: Liberty Fund.

Bridgman, Percy. 1928. The logic of modern physics. New York: Macmillan.

Broer, Tineke, and Martyn Pickersgill. 2015. Targeting brains, producing responsibilities: the use of neuroscience within British social policy. Social Science \& Medicine, 132: 54-61.

Buchanan, James. 1972. A defense of organized crime? In The economics of crime and punishment, ed. S. Rottenberg. Washington D.C.: American Enterprise Institute, 119-132.

Caldwell, Bruce. 2010. Introduction. In The collected works of F.A. Hayek, volume XIII: studies on the abuse and decline of reason, ed. Bruce Caldwell. Chicago: University of Chicago Press, 1-45.

Cameron, Samuel. 1989. A subjectivist perspective on the economics of crime. Review of Austrian Economics, 1 (2): 31-43.

Canuel, Mark. 2007. The shadow of death: literature, romanticism, and the subject of punishment. Princeton: Princeton University Press.

Cavadino, Michael, and James Dignan. 2006. Penal systems: a comparative approach. Los Angeles: Sage.

Chadwick, Edwin. 1829. A preventive police. London Review, 1: 252-308.

Clemmer, Donald. 1958 [1940]. The prison community. New York: Rinehart \& Winston. 
Cloward, Richard, Donald Cressey, George Grosser, Richard McCleary, Lloyd Ohlin, Gresham Sykes, and Sheldon Messinger. 1960. Theoretical studies in social organization of the prison. Washington D.C.: Social Science Research Council.

Cornuelle, Richard. 1965. Reclaiming the American dream: the role of private individuals and voluntary associations. London: Transaction.

Cornuelle, Richard. 1983. Healing America: what can be done about the continuing economic crises. New York: Putnam.

Coyne, Christopher. 2008. After war: the political economy of exporting democracy. Palo Alto: Stanford Economics and Finance.

Coyne, Christopher. 2013. Doing bad by doing good: why humanitarian action fails. Palo Alto: Stanford Economics and Finance.

Cullen, Francis, Robert Agnew, and Pamela Wilcox. 2002. Criminological theory: past to present: essential readings. Oxford: Oxford University Press.

D'Amico, Daniel. 2010. The prison in economics: private and public incarceration in ancient Greece. Public Choice, 145 (3-4): 461-482.

Davis, Lawrence. 1972. They deserve to suffer. Analysis, 32 (4): 136-140.

Demsetz, Harold. 1967. Towards a theory of property rights. American Economic Review, 57 (2): 347-359.

Descartes, Rene. 1999 [1637]. Discourse on the method. Indianapolis: Hackett Publishing Company.

Dilulio, John. 1996. Help wanted: economists, crime and public policy. Journal of Economic Perspectives, 10 (1): 1-34.

Donohue, John, and Steven Levitt. 2004. Further evidence that legalized abortion lowered crime: a reply to Joyce. Journal of Human Resources, 39 (1): 29-49.

Durkheim, Emile. 1982 [1895]. Rules of the sociological method. Florence: The Free Press.

Durkheim, Emile. 1997 [1893]. Division of labor in society. Florence: The Free Press.

Easterly, William. 2002. The elusive quest for growth: economists' adventures and misadventures in the tropics. Cambridge (MA): MIT Press.

Easterly, William. 2007. The white man's burden: why the west's efforts to aid the rest have done so much ill and so little good. London: Penguin Books.

Ehrlich, Isaac. 1972. The deterrent effect of criminal law enforcement. Journal of Legal Studies, 12 (2): 289-332.

Ehrlich, Isaac. 1975. The deterrent effect of capital punishment: a question of life and death. American Economic Review, 65 (3): 397-417.

Ehrlich, Isaac. 1977. The deterrent effect of capital punishment: reply. American Economic Review, 67 (3): 452-458.

Ehrlich, Isaac. 1981. On the usefulness of controlling individuals: an economic analysis of rehabilitation, incapacitation, and deterrence. American Economic Review, 71 (3): 307-322.

Ehrlich, Isaac. 1982. On positive methodology, ethics, and polemics in deterrence research. British Journal of Criminology, 22 (2): 124-139.

Elias, Norbert. 1969. The history of manners: the civilizing project, vol. 1. Oxford: Blackwell.

Feeley, Malcolm, and Jonathan Simon. 1992. The new penology: notes on the emerging strategy of corrections and its implications. Criminology, 30 (4): 449-474. 
Ferguson, Adam. 1996 [1767]. An essay on the history of civil society. Cambridge: Cambridge University Press.

Ferri, Enrico. 1996 [1884]. Criminal sociology. Salt Lake City: Project Gutenberg.

Ferri, Enrico. 2004 [1901]. The positivist school of criminology. Salt Lake City: Project Gutenberg.

Friedman, David. 1979. Private creation and enforcement of law: a historical case. Journal of Legal Studies, 8: 399-415.

Friedman, David. 1989. The machinery of freedom: a guide to a radical capitalism. Chicago: Open Court Publishing.

Friedman, David. 1999. Why not hang them all: the virtues of inefficient punishment. Journal of Political Economy, 107 (S6): S259-269.

Friedman, Lawrence. 1994. Crime and punishment in American history. New York: Basic Books.

Flanagan, Timothy, and Dennis Longmire (eds.). 1996. Americans view crime and justice, a national public opinion survey. Thousand Oaks: Sage.

Foucault, Michel. 1964. Madness and civilization: a history of insanity in the age of reason. New York: Pantheon Books.

Foucault, Michel. 1975. Discipline and punish: the birth of the prison. New York: Vintage Books.

Gambetta, Diego. 1996. The Sicilian mafia: the business of private protection. Cambridge (MA): Harvard University Press.

Gambetta, Diego. 2011. Codes of the underworld: how criminals communicate. Princeton: Princeton University Press.

Garland, David. 2000. The culture of high crime societies: some preconditions of recent 'law and order' policies. British Journal of Criminology, 40 (3): 347-375.

Garland, David (ed.). 2001. Mass imprisonment: social causes and consequences. Thousand Oaks: Sage.

Gatrell, V. A. C. 1980. The decline of theft and violence in Victorian and Edwardian England. In Crime and the law: the social history of crime in western Europe since 1500, eds. V. Gatrell, B. Lenman, and G. Parker. London: Europa, 238-337.

Geltner, Guy. 2008. The medieval prison: a social history. Princeton: Princeton University Press.

Gladwell, Malcolm. 2002. The tipping point: how little things can make a big difference. New York City: Back Bay Books.

Glenn, Andrea, and Adrian Raine. 2014. Neurocriminology: implications for the punishment, prediction and prevention of criminal behavior. Nature Reviews Neuroscience, 15 (1): 54-63.

Goebel, Julius. 1937. Felony and misdemeanor: a study in the history of criminal law. Philadelphia: University of Pennsylvania Press.

Goffman, Erving. 1957. Asylums: essays on the social situation of mental patients and other inmates. New York: Anchor Books.

Hamowy, Ron. 1977. Medicine and the crimination of sin: 'self-abuse' in 19th century America. Journal of Libertarian Studies, 3 (3): 229-270.

Harcourt, Bernard. 2011. The illusion of free markets: punishment and the myth of natural order. Cambridge (MA): Harvard University Press.

Hayek, Friedrich. 1935. The present state of the debate. In Collectivist economic planning, ed. Friedrich Hayek. London: Lowe and Brydone, 201-244. 
Hayek, Friedrich. 1948 [1945]. Individualism true and false. In Individualism and economic order, by Friedrich Hayek. Chicago: University of Chicago Press, 1-32.

Hayek, Friedrich. 1949. The intellectuals and socialism. University of Chicago Law Review, 16 (3): 417-433.

Hayek, Friedrich. 1952 [1941]. The counter-revolution of science on the abuse of reason. Indianapolis: Liberty Fund.

Hayek, Friedrich. 1960. The constitution of liberty. Chicago: University of Chicago Press.

Hayek, Friedrich. 1973. Law, legislation, and liberty, 3 vols. Chicago: University of Chicago Press.

Hayek, Friedrich. 2010. The collected works of F.A. Hayek, vol. XIII: studies on the abuse and decline of reason, ed. Bruce Caldwell. Chicago: University of Chicago Press.

Hazlitt, Henry. 1946. Economics in one lesson: the shortest and surest way to understand basic economics. New York: Harper.

Higgs, Robert. 2004. Against leviathan: government power and a free society. Oakland: The Independent Institute.

Hobbes, Thomas. 1996 [1651]. Leviathan. Cambridge: Cambridge University Press.

Hoebel, E. Adamson. 2006. The law of primitive man: a study in comparative legal dynamics. Cambridge (MA): Harvard University Press.

Hume, David. 2005 [1739]. A treatise of human nature. Oxford: Clarendon.

Irwin, John, and Donald Cressey. 1963. Thieves, convicts and the inmate culture. Social Problems, 10 (2): 142-155.

Johnsen, D. Bruce. 1986. The formation and protection of property rights among the southern Kwakiutl Indians. Journal of Legal Studies, 15 (1): 41-67.

Johnston, Norman. 2000. Forms of constraint: a history of prison architecture. Champaign: University of Illinois Press.

Kahneman, Daniel. 2003. Maps of bounded rationality: psychology for behavioral economics. American Economic Review, 93 (5): 1449-1475.

Kleiman, Mark. 2009. When brute force fails: how to have less crime and less punishment. Princeton: Princeton University Press.

Kleining, John. 1973. Punishment and desert. New York: Springer.

Kyckelhahn, Tracey. 2012. State corrections expenditures: FY 1982-2010. Washington D.C.: US Dept. of Justice.

Lacassagne, Alexandre. 1891. Preface. In Les habitués des prisons de Paris: étude d'anthropologie \& psycholgie criminelles, by E. Laurent. Edinburgh: Royal College of Physicians.

Lacey, Nicola. 2008. The prisoners' dilemma: political economy and punishment in contemporary democracies. Cambridge: Cambridge University Press.

Leeson, Peter. 2009. The invisible hook: the hidden economics of pirates. Princeton: Princeton University Press.

Levitt, Steven. 1996. The effect of prison population size on crime rates: evidence from prison overcrowding litigation. Quarterly Journal of Economics, 111 (2): 319-351.

Lipton, Douglas, Robert Martinson, and Judith Wilks. 1975. The effectiveness of correctional treatment: a survey of treatment evaluation studies. Santa Barbara: Praeger.

Lombroso, Cesare. 1911. Crime: its causes and remedies. Boston: Little Brown and Company. 
Lott, John. 1998. More guns, less crime: understanding crime and gun control laws. Chicago: University of Chicago Press.

Loury, Glenn. 2008. Race, incarceration and American values. Boston: Boston Review Books.

Maine, Henry. 2013 [1861]. Ancient law: its connection to the history of early society. Oxford: Oxford University Press.

Martinson, Robert. 1974. What works?-questions and answers about prison reform. Public Interest, 25: 22-54.

McConville, Sean. 1995. The Victorian prison: England, 1865-1965. In The Oxford history of the prison: the practice of punishment in western society, eds. N. Morris and D. Rothman. Oxford: Oxford University Press, 117-150.

Menger, Carl. 1994 [1871]. Principles of economics. Grove City: Libertarian Press.

Meskell, Matthew. 1999. An American resolution: the history of prisons in the United States from 1777 to 1877. Stanford Law Review. 51 (4): 839-865.

Mill, John Stuart. 1982 [1826]. Essays on England, Ireland and the empire. Toronto: University of Toronto Press.

Mill, John Stuart. 1869. The subjection of women. London: Longmans, Green, Reader and Dyer.

Mises, Ludwig. 1957. Theory and history. Auburn: Ludwig von Mises Institute.

Morris, Norval. 1995. The contemporary prison: 1965-present. In The Oxford history of the prison: the practice of punishment in western society, eds. N. Morris and D. Rothman. Oxford: Oxford University Press, 202-234.

Moskos, Peter. 2011. In defense of flogging. New York: Basic Books.

Montesquieu. 1989 [1748]. The spirit of the laws. Cambridge: Cambridge University Press.

Mundle, Clement. 1969. Punishment and desert. In The philosophy of punishment, ed. H. Acton. New York: St. Martin's Press, 65-80.

North, Douglass. 1990. Institutions, institutional change and economic performance. Cambridge: Cambridge University Press.

O'Brien, Patricia. 1995. The prison on the continent: Europe, 1865-1965. In The Oxford history of the prison: the practice of punishment in western society, eds. N. Morris and D. Rothman. Oxford: Oxford University Press, 178-201.

Olson, Mancur. 1971. The logic of collective action: public goods and the theory of groups. Cambridge (MA): Harvard Economic Studies.

Olson, Mancur. 1982. The rise and decline of nations: economic growth, stagflation, and social rigidities. New Haven: Yale University Press.

Ostrom, Elinor, and Daniel Cole. 2011. Property in land and other resources. Cambridge: Lincoln Institute of Land Policy.

Passell, Peter. 1975. The deterrent effect of death penalty: a statistical test. Stanford Law Review, 28: 61-80.

Passell, Peter, and John Taylor. 1976. The deterrence controversy: reconsideration of the time series evidence. In Capital Punishment, eds. H. Bedau and C. Pierce. New York: AMS Press, 359-371.

Passell, Peter, and John Taylor 1977. The deterrent effect of capital punishment: another view. American Economic Review, 67 (3): 445-451.

Peart, Sandra, and David Levy. 2005. The 'vanity of the philosopher' from equality to hierarchy in post-classical economics. Ann Arbor: University of Michigan Press. 
Pease, Ken. 1992. Punitiveness and prison populations: an international comparison. Justice of the Peace, 156: 405-408.

Pinker, Steven, 2011. The better angels of our nature: why violence has declined. New York: Viking.

Posner, Richard. 1980. A theory of primitive society, with special reference to primitive law. Journal of Law and Economics, 23 (1): 1-53.

Posner, Richard. 1981. The economics of justice. Cambridge: Cambridge University Press.

Putnam, Robert. 2001. Bowling alone: the collapse and revival of American community. New York: Simon \& Schuster.

Reimer, Hans. 1937. Socialization in the prison community. Proceedings of the SixtySeventh Annual Congress of American Prison Association: 151-155.

Reuter, Peter. 1983. Disorganized crime: the economics of the visible hand. Cambridge (MA): MIT Press.

Rhodes, Lorna. 2004. Total confinement: madness and reason in the maximum security prison. Berkley: University of California Press.

Rizzo, Mario. 1980. Law amid flux: the economics of negligence and strict liability in tort. Journal of Legal Studies, 9 (2): 291-318.

Roberts, Julian, Loretta Stalans, David Indermaur, and Mike Hough. 2003. Penal populism and public opinion: lessons from Five Countries. Oxford: Oxford University Press.

Rothman, David. 1971. The discovery of the asylum. Piscataway: Transaction.

Rothman, David. 1980. Conscience and convenience the asylum and its alternatives in progressive America. Piscataway: Transaction.

Rubin, Ashley T. 2013. Institutionalizing the Pennsylvania system: organizational exceptionalism, administrative support, and Eastern State Penitentiary, 1829-1875. $\mathrm{PhD}$ thesis, University of California, Berkeley.

Rubin, Ashley T. 2015. A neo-institutional account of prison diffusion. Law \& Society Review, 49 (2): 365-399.

Schrag, Clarence. 1944. Social types in a prison community. Master's thesis, University of Washington.

Sellin, Thorsten. 1931. The historical background of our prisons. The ANNALS of the American Academy of Political and Social Science, 157 (1): 1-5.

Shaw, Clifford, and Henry McKay. 1972. Juvenile delinquency and urban areas. Rutland: Phoenix Books.

Skarbek, David. 2014. The social order of the underworld: how prison gangs govern the American penal system. Oxford: Oxford University Press.

Smith, Adam. 1982 [1763]. Lectures on justice, police, revenue, and arms. In Lectures on jurisprudence, eds. R. L. Meek, D. D. Raphael, and P. G. Stein. Indianapolis: Liberty Fund.

Smith, Adam. 2009 [1759]. The theory of moral sentiments. Indianapolis: Liberty Fund.

Smith, Adam. 1904 [1776]. An inquiry into the nature and causes of the wealth of nations. Indianapolis: Liberty Fund.

Spierenburd, Peter. 1991. The prison experience: disciplinary institutions and their inmates in early modern Europe. New Brunswick: Rutgers University Press.

Stephan, James. 2004. State prison expenditures: 2001. Washington D.C.: US Dept. of Justice. 
Sutton, John. 2004. The political economy of imprisonment in affluent western democracies, 1960-1990. American Sociological Review, 69 (2): 170-189.

Sykes, Gresham. 1958. Society of captives. Princeton: Princeton University Press.

Szasz, Thomas. 1973. The age of madness: a history of involuntary mental hospitalization. New York: Routledge.

Taubes, Gary. 2007. Good calories, bad calories: fat, carbs, and the controversial science of diet and health. New York: Anchor.

Taubes, Gary. 2010. Why we get fat: and what to do about it. New York: Anchor.

Tobias, John. 1979. Crime and police in England, 1700-1900. New York: St. Martin's Press.

Tocqueville, Alexis de. 1990a [1835]. Democracy in America, vol I., ed. Eduardo Nolla Indianapolis: Liberty Fund.

Tocqueville, Alexis de. 1990b [1840]. Democracy in America volumes, vol. II., ed. Eduardo Nolla Indianapolis: Liberty Fund.

Tonry, Michael (ed.). 2007. Crime, punishment, and politics in comparative perspective. In Crime and Justice: A Review of Research, vol. 36. Chicago: University of Chicago Press.

Wacquant, Loic. 2009. Punishing the poor: the neoliberal government of social insecurity. Durham: Duke University Press.

Walker, Nigel, and Mike Hough. 1988. Public attitudes to sentencing: surveys from five countries. Aldershot: Gower

Walmsley, Roy. 2003. Global incarceration and prison trends. Forum on Crime and Society, 3 (1-2): 65-78.

Weber, Max. 1946. From Max Weber: essays in sociology, eds. H. Gerth and C. Mills. Oxford: Oxford University Press.

Whitman, James. 2003. Harsh justice: criminal punishment and the widening divide between America and Europe. Oxford: Oxford University Press.

Whitman, James. 2007. What happened to Tocqueville's America? Social Research, 74 (2): 251-268.

Wilson, James. 1975. Thinking about crime. New York: Basic Books.

Wilson, James, and Richard Hernnstein. 1985. Crime \& human nature, the definitive study of the causes of crime. New York: Touchstone.

Daniel D'Amico is a lecturer in economics at Brown University and associate director of the Political Theory Project.

Contact e-mail: <daniel_damico@brown.edu> 